\title{
Review of Reactors with Potential Use in Thermochemical Energy Storage in Concentrated Solar Power Plants
}

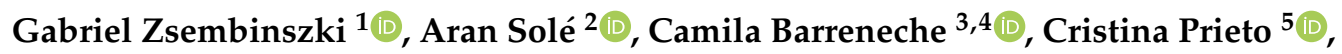 \\ A. Inés Fernández ${ }^{3}$ and Luisa F. Cabeza ${ }^{1, *(D)}$ \\ 1 GREiA Research Group, INSPIRES Research Centre, University of Lleida, Pere de Cabrera s/n, \\ 25001 Lleida, Spain; gabriel.zsembinszki@udl.cat \\ 2 Department of Mechanical Engineering and Construction, Universitat Jaume I, Campus del Riu Sec s/n, \\ 12071 Castelló de la Plana, Spain; sole@uji.es \\ 3 Department of Materials Science and Physical-Chemistry, Universitat de Barcelona, Martí i Franqués 1, \\ 08028 Barcelona, Spain; c.barreneche@ub.edu (C.B.); ana.inesfernandez@ub.edu (A.I.F.) \\ 4 BCES (Birmingham Centre of Energy Storage), School of Chemical Engineering, University of Birmingham, \\ Birmingham B15 2TT, UK \\ 5 Abengoa, C/Energía Solar 1, 41012-Seville, Spain; cristina.prieto@abengoa.com \\ * Correspondence: lcabeza@diei.udl.cat; Tel.: +34-973-003576
}

Received: 7 August 2018; Accepted: 3 September 2018; Published: 6 September 2018

check for updates

\begin{abstract}
The aim of this study is to perform a review of the state-of-the-art of the reactors available in the literature, which are used for solid-gas reactions or thermal decomposition processes around $1000{ }^{\circ} \mathrm{C}$ that could be further implemented for thermochemical energy storage in CSP (concentrated solar power) plants, specifically for SPT (solar power tower) technology. Both direct and indirect systems can be implemented, with direct and closed systems being the most studied ones. Among direct and closed systems, the most used configuration is the stacked bed reactor, with the fixed bed reactor being the most frequent option. Out of all of the reactors studied, almost $70 \%$ are used for solid-gas chemical reactions. Few data are available regarding solar efficiency in most of the processes, and the available information indicates relatively low values. Chemical reaction efficiencies show better values, especially in the case of a fluidized bed reactor for solid-gas chemical reactions, and fixed bed and rotary reactors for thermal decompositions.
\end{abstract}

Keywords: high temperature; concentrated solar power (CSP); thermochemical energy storage (TCM); solid-gas reactors; review

\section{Introduction}

The production of electricity from concentrated solar power plants, which are known as CSP plants, is still a maturing technology, although it has been in operation commercially at the utility scale since 1985 [1]. Nevertheless, it has experienced a worldwide large increase in deployment in recent years [2], and there are plans to expand its application in industrial processes and the generation of solar fuels. According to the Renewable Energy Policy Network for the 21st Century (REN21) [3], total installed capacity in CSP in 2016 was $4.81 \mathrm{GW}$, growing from $600 \mathrm{MW}$ in 2009. The deployment was mostly in Spain (with $2300 \mathrm{MW}$ ) and the United States (USA) (with $1738 \mathrm{MW}$ ). Other countries with plants are India, Morocco, South Africa, the United Arab Emirates, Algeria, Egypt, Australia, China, and Thailand. Today, parabolic trough technology dominates the CSP market, both in number of projects and total installed capacity (around $85 \%$ of capacity) [4]. 
Moreover, according to different sources, the future deployment of CSP around the world is bright. The International Renewable Energy Agency (IRENA) [5] stated that CSP will grow between 52 GW (44 GW according to its REmap [6]) and 83 GW with the reference and Remap 2030 scenario, respectively. On the other hand, the International Energy Agency (IEA) [7] reported a CSP capacity installed of $110 \mathrm{GW}$ in its 450 scenarios. According to IEA [8], under a high renewable energy scenario, $11 \%$ of electricity generation will come from CSP in 2050, with 954 GW of installed capacity. In the IEA CSP technology roadmap [9], the IEA updated the installed capacity to $982 \mathrm{GW}$ in 2050. Finally, the European Solar Thermal Electricity Association (ESTELA), the CSP European industry association, reported a worldwide implementation of $1080 \mathrm{GW}$ in 2050 [10].

Del Río et al. [2] analyzed the drivers and barriers of the deployment of CSP in Europe. Those authors concluded that these drivers and barriers include techno-economic, administrative, policy, and social acceptance factors. According to them, the most relevant barriers are the high costs of the technology and uncertain and retroactive policies.

The biggest technological drawback of solar energy is its temporal intermittency. To overcome this problem, backup systems can be used in the so-called hybrid plants, where fossil fuel or biomass is burned; another solution is the use of thermal energy storage (TES) [11-14]. Prieto et al. [15] stated that there is a need to extend the operation of a CSP plant up to $15 \mathrm{~h}$, in order to achieve a plant that is more versatile to comply with unexpected peak demand during nighttime, where no power is being produced. Moreover, the reliance during operating hours would increase.

There are three technologies for TES: sensible energy storage, latent energy storage, and thermochemical energy storage (which include sorption and chemical reactions) [16,17]. Ming et al. [18] reviewed the literature on TES for CSP. These authors concluded that current research efforts in the area of sensible TES focus on the development of new molten salts with lower freezing temperatures and higher decomposition temperatures, the development of ionic liquids for next generation heat transfer fluids (HTFs), the utilization of nanotechnology to improve the specific heat capacity and thermal conductivity, and the development of low-cost solid storage media and their evaluation through compatibility tests with molten salts. On the other hand, the research on latent TES for CSP plants has aimed at increasing the thermal conductivity of phase change materials (PCM) through encapsulation, utilizing heat pipes, and making PCMs mobile—-the so-called dynamic PCM-in order to increase the discharge phase.

In CSP, sensible energy storage is the most mature technology, as well as the only that is commercially available today [19]. Sensible storage can be found in commercial plants such as the PS10 and PS20 projects (2007 and 2009), and the Andasol 1 and Andasol 2 plants (2008) in Spain, and the Solar One plant (1982) in the USA [15]. Today, two TES technologies are currently implemented in commercial CSP plants: the so-called Ruth's storage for direct steam generation plants, and the two-tank molten salts technology [16].

A cost comparison between these two commercial TES systems for CSP was carried out by González-Roubaud et al. [19] using a levelized cost of electricity (LCOE) calculation. This metric is used in power generation in order to compare the cost of electricity between sources. The results show that the Ruth accumulator has the lowest thermal cost for storage capacities lower than $3 \mathrm{~h}$, followed by the direct and indirect molten salt TES. The trend reverses when storage capacities increase.

A parallel study was done by Dowling et al. [20], where an economic assessment of complete CSP plants with two different methods, LCOE and revenue, was presented. They demonstrated that the value of TES is not correctly captured when the LCOE is used, since this does not include the economic opportunities coming from the time-varying value of electricity (which are increasing as more non-dispatchable renewable power is included in the grid). These authors state that storage capacity increases the flexibility of CSP generators, as well as the revenues that are available to them.

The second storage technology, latent heat storage, allows large amounts of energy to be stored in relatively small volumes (high energy density) [21]. Although there are several studies [22-25] related 
to the use of phase change materials (PCM, the materials used in latent heat storage) in CSP plants, this technology is still not installed in commercial plants.

Finally, thermochemical energy storage is receiving increasing attention among researchers. Prieto et al. [15] presented a review of chemical reaction processes for CSP from the technological point of view. The authors presented the different cycles that have been studied by other researchers, such as sulfur base cycles and metal oxide redox cycles (calcium carbonate cycle, calcium hydroxide cycle, and manganese oxide cycle), and perovskite-form structures. Previously, reaction candidates for medium or high-temperature applications $\left(250-800{ }^{\circ} \mathrm{C}\right)$ were listed by Felderhoff et al. [26]. The listed candidates included metal hydrides, metal hydroxides, and metal carbonates. In 2014, Pardo et al. [27] published a state-of-the-art of the thermochemical heat storage solutions, focusing on temperatures comprised between 573-1273 K, and not focused only on CSP applications, but more generally on high temperature. The materials listed are metal hydrides, carbonate systems, hydroxide systems, redox systems, ammonia systems, and organic systems. In their conclusions, these authors claimed that thermochemical energy storage appears to be the most promising TES system for solar plants during long periods, because both the storage period and transport distance are theoretically unlimited, since there is no loss of heat during storage (storage happens at ambient temperature).

Although some of these reviews present and comment on the different configurations and prototypes used for each material or reaction, none of them has provided a detailed assessment of the reactor itself. Therefore, the aim of this new review is to fill this gap found in the literature, evaluating the reactor concepts, and highlighting their advantages and disadvantages.

\section{Materials Used in Thermochemical Reactions}

Currently, there are different processes using solar energy, from CSP plant technology to performing a chemical reaction [28-32]. All of them have in common the objective of reducing fossil fuel consumption, and therefore reducing $\mathrm{CO}_{2}$ emissions. The different processes that require solar reactors and also working temperatures above $1000{ }^{\circ} \mathrm{C}$ are two-step thermochemical $\mathrm{H}_{2} \mathrm{O} / \mathrm{CO}_{2}$ splitting, the gasification/cracking of carbonaceous feedstock, thermochemical heat storage, and the recycling/procurement of raw materials.

The two-step thermochemical $\mathrm{H}_{2} \mathrm{O} / \mathrm{CO}_{2}$ splitting $[33,34]$ is based on a two-redox reaction cycle for $\mathrm{CO}$ and $\mathrm{H}_{2}$ production, which is considered as solar fuel. This gas is used as fuel for fuel cells or feedstock for in Fischer-Tropsch reactions. In this case, in order to split $\mathrm{CO}_{2}$ and $\mathrm{H}_{2} \mathrm{O}$ molecules, a metal oxide is used to perform a thermal reduction of metal oxide, obtaining a metal (or metal oxide) (Equation (1)) that is capable of reducing (split) $\mathrm{CO}_{2}$ or $\mathrm{H}_{2} \mathrm{O}$ (Equation (2)). Depending on the metal oxide, the working temperature or the system pressure must be adjusted [35]. In addition, in Equation (1), the key is the solid product of the reaction, while in Equation (2), the important step is the gas product. These key issues will be the points affecting the reactor design.

$$
\begin{gathered}
\mathrm{MO}_{\mathrm{x}}+\mathrm{Q} \rightarrow \mathrm{MO}_{\mathrm{x}-\mathrm{y}}+\frac{\mathrm{y}}{2} \mathrm{O}_{2} \\
\mathrm{MO}_{\mathrm{x}-\mathrm{y}}+\mathrm{yCO}_{2} / \mathrm{H}_{2} \mathrm{O} \rightarrow \mathrm{MO}_{\mathrm{x}}+\mathrm{yCO} / \mathrm{H}_{2}
\end{gathered}
$$

The processes gasification/cracking of carbonaceous feedstock $[29,36]$ are based on biogas cracking (Equation (3)) or carbonaceous feedstock gasification (Equation (4)) to obtain solar fuel, for fuel cell or for a Fischer-Tropsch reaction. When necessary, these reactions can be performed under catalytic reaction to accelerate kinetics. A system for collecting the gases will be significant for the reactor design in this type of process:

$$
\begin{gathered}
\mathrm{C}_{\mathrm{x}} \mathrm{H}_{\mathrm{y}}+\mathrm{Q} \rightarrow \mathrm{xC}+\frac{\mathrm{y}}{2} \mathrm{H}_{2} \\
\mathrm{CH}_{\mathrm{x}} \mathrm{O}_{\mathrm{y}}+(1-\mathrm{y}) \mathrm{H}_{2} \mathrm{O}+\mathrm{Q} \rightarrow\left(\frac{\mathrm{x}}{2}+1-\mathrm{y}\right) \mathrm{H}_{2}+\mathrm{CO}
\end{gathered}
$$


Thermochemical energy storage $[26,27]$ is designed to store heat through a reversible reaction (Equation (5)). A heat exchanger is required for this process in order to revert the solar heat that has been stored. However, although this technology/process has still not been neither extensively studied nor implemented, its definition can be found in the literature [37].

$$
\mathrm{MO}_{\mathrm{x}}+\mathrm{Q} \leftrightarrow \mathrm{MO}_{\mathrm{x}-\mathrm{y}}+\frac{\mathrm{y}}{2} \mathrm{O}_{2}
$$

Finally, there is the recycling/procurement of raw materials. As it is well known, many processes for obtaining raw materials, such as $\mathrm{Zn}$ or $\mathrm{CaO}$, require high-energy inputs to perform a carbothermal reduction. In this case, several materials can sustain thermal reductions by using concentrated solar power.

As mentioned above, all of the processes prioritize some design aspects (heat exchanger, product collection, versatility, etc.). However, all of them can be classified according the reaction type, heating system, or limiting step of process (reaction, diffusion, etc.).

\section{Classification of Reactors}

There are several ways to classify the solar reactors depending on the focus. Classifications based on the reactor or on the system can be found in the literature $[28,38]$. Therefore, a new classification is suggested based on the process by itself, which is at the end what will give us the limiting step. The limiting step is essential to properly designing the reactor and the system containing the future TCM (thermochemical material) selected reaction, which will be implemented in solar power tower (SPT) technology.

\subsection{Classification Based in the Reactor}

Figure 1 shows the classification of the reactors that has been taken into account in Table 1 . Within stacked beds (modular ones), fixed beds are recommended for solar catalytic reactions. For those reactions that require good thermal transfer properties, Villermaux [38] suggested the employment of fluidized beds. Cyclones are interesting if the further separation between solid and gas is desired, but their use is similar in terms of the ad/disadvantages of fluidized bed reactors (Table 1).

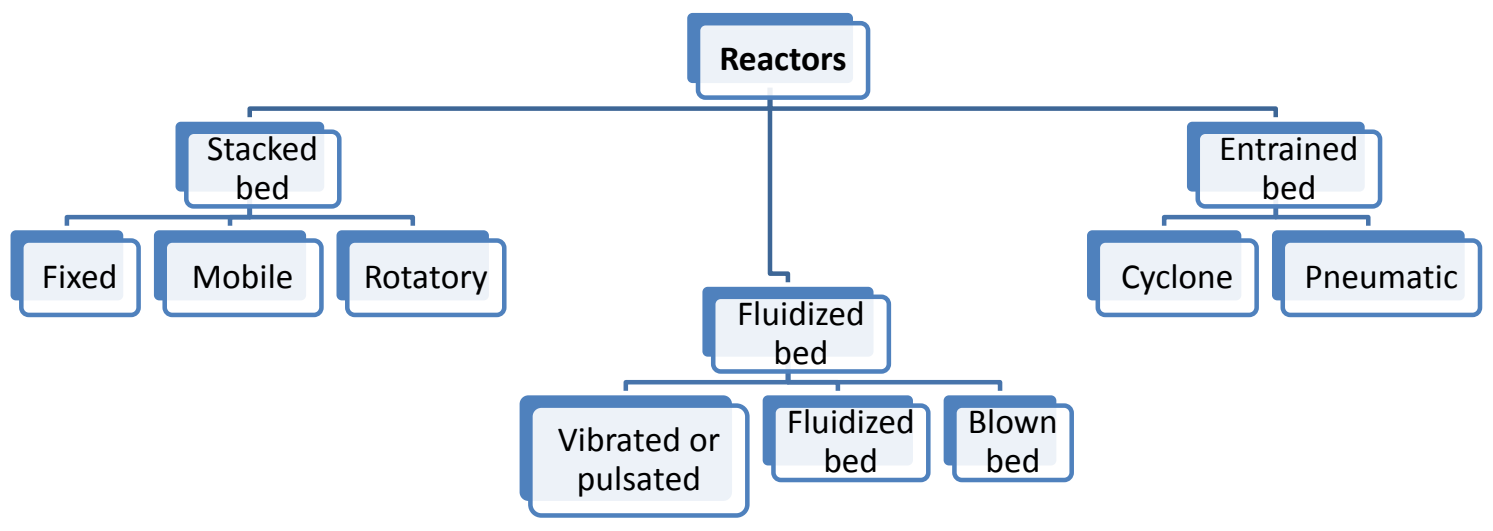

Figure 1. Classification according to the reactor type.

Following a flow pattern classification, three main gas-solid technologies can be found, including fixed, moving and fluidized bed [39]. Their main advantages and disadvantages are shown in Table 1. In fixed bed reactors (also called packed bed reactors), the solid particles are located inside a vessel with the flux of reactants flowing through the stationary bed. When the diameter of the packed bed increases, heat transfer rates are poor; therefore, high heat transfer rates should be considered when fluidized beds are required [40]. In mobile/moving bed reactors, the bed can be moved continuously 
or periodically with a fluid circulation similar to the prior one. In addition, in fluidized bed reactors, the solid has a very small diameter and is maintained in suspension.

Table 1. Comparison between fixed, moving, and fluidized bed reactors for solar applications [41].

\begin{tabular}{|c|c|c|}
\hline Reactor & Advantages & Disadvantages \\
\hline Fixed/packed bed & $\begin{array}{c}\text { Low cost } \\
\text { Non-parasitic } \\
\text { Easier for modeling }\end{array}$ & $\begin{array}{l}\text { Low heat and mass transfer } \\
\text { High-pressure drop } \\
\text { Difficulties to be implemented in solar } \\
\text { receiver cavities at continuous } \\
\text { commercial process } \\
\text { Stacked bed needed, with higher } \\
\text { complexity in solar-focused strategies } \\
\text { Non-uniform irradiance distributions on } \\
\text { the particle volume }\end{array}$ \\
\hline Mobile/moving bed & $\begin{array}{l}\text { Direct heat transfer between solids } \\
\text { and the gas } \\
\text { Increase of the heat transfer coefficient }\end{array}$ & $\begin{array}{l}\text { Difficulties to be implemented in solar } \\
\text { reactors } \\
\text { Non-uniform irradiance distributions on } \\
\text { the particle flow } \\
\text { Need to control the residence time to } \\
\text { increase the heat transference in particle } \\
\text { receiver } \\
\text { Complex hydrodynamics }\end{array}$ \\
\hline Rotary & $\begin{array}{c}\text { High chemical conversion due to high } \\
\text { heat and mass transfer } \\
\text { Versatility } \\
\text { Long life components }\end{array}$ & $\begin{array}{l}\text { Difficulties of scalability to lager } \\
\text { commercial solar systems } \\
\text { Increase of parasitic energy consumption } \\
\text { due to the movement of the reactor } \\
\text { Higher risk of mechanical maintenance } \\
\text { cost due to the use of a rotatory element } \\
\text { at high temperature }\end{array}$ \\
\hline Fluidized bed & $\begin{array}{l}\text { Minimization of the risk of hotspots } \\
\text { and thermal instability } \\
\text { Heat transfer coefficients are high }\end{array}$ & $\begin{array}{l}\text { Difficulties to be implemented in solar } \\
\text { reactors } \\
\text { Need of gas for fluidization } \\
\text { Increase of parasitic energy consumption } \\
\text { due to the need of fluidized gas } \\
\text { Erosion of internal components } \\
\text { Complex reactor hydrodynamics and } \\
\text { modeling }\end{array}$ \\
\hline
\end{tabular}

\subsection{Classification Based in the System}

As mentioned in Table 1, the implementation of the reactors in the solar plant is the main problem for the system configuration. A possible classification based on the irradiation and the solar receiver can be established according to the heat integration mode into the reaction chamber. This is related with the maximum system efficiency (solar-to-chemical). Furthermore, solar reactors are indirect or direct, as shown in Figure 2.

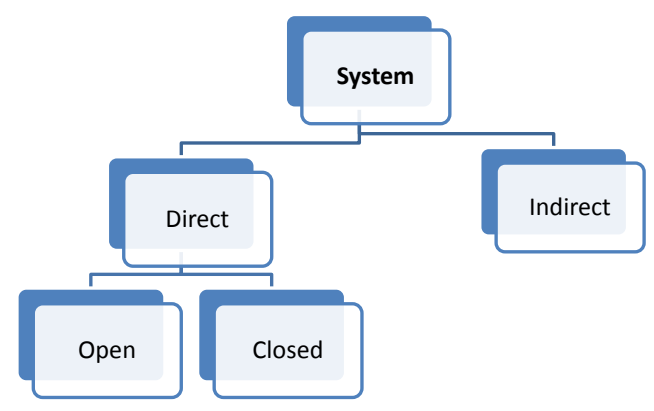

Figure 2. Classification according to the system. 
Indirect reactors are those where a container material is directly irradiated to heat the solid or the heat transfer fluid. This configuration is mostly used for fluidized beds, where the solid can be forced upward through irradiated tubes by an airflow, which fluidizes the particles and increases the heat transfer from the tube walls to the flowing particles $[28,42]$.

On the other hand, in direct reactors, reactants are directly irradiated and heated by a solar radiation input. Some of them have a receiver aperture that can be opened (open reactor) or closed by a transparent window (mainly quartz-closed reactors). The quartz window is mandatory in a direct system at high temperature in order to reduce the heat and mass losses. The design of a suitable window for high-temperature processes $\left(\mathrm{T}>900^{\circ} \mathrm{C}\right)$ is still a bottleneck in the design of solar receivers.

Therefore, for direct reactors (both configurations: open and closed), it is important to consider the absorptivity/emissivity of the material, since the more radiation that is absorbed, the higher the reactor efficiency and conversion, because the materials are basically heated by radiation, although they are also heated by convection and conduction. Higher temperatures are expected within direct reactors when compared to indirect reactors, but it is difficult to get homogeneous temperatures inside the reaction chamber.

On the other hand, an indirect system is defined as a system that uses concentrated solar power to heat a black body, and then transfers the heat to the reaction cavity by conduction and convection. Therefore, an indirect reactor requires a thermal conductor between the receiver and reactor to heat the reaction cavity [43]. However, such systems minimize the thermal shock (the temperature gradients are lower than in direct reactors) by maintaining a uniform temperature inside the reaction chamber.

Energy efficiency is directly affected by this choice, since when transferring sun energy to a material, there is always some losses, which at the end is translated to less system efficiency. The indirect system implies one more resistance than the direct system.

\subsection{Classification Based in the Process Limiting Step}

The classification shown in Figure 3 is suggested by the authors. From the point of view of our knowledge, it is very important to distinguish between a reaction with two phases and a decomposition of a solid due to the effect of heat. This classification enables us to make a relation with the limiting step of the process inside the reactor. Moreover, the limiting step (chemical or diffusive controlled) must be identified in order to start the reactor design.

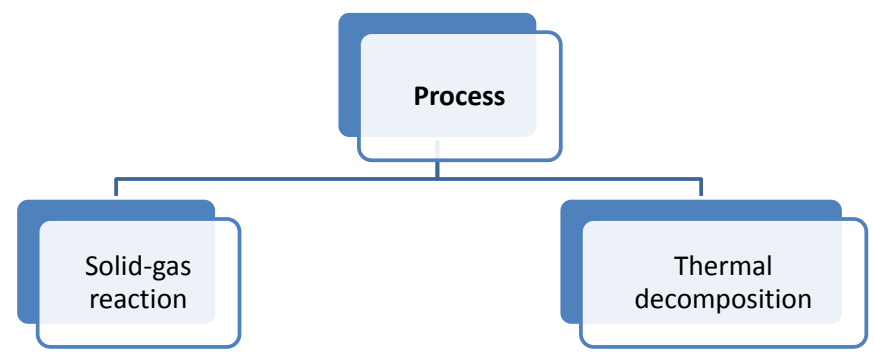

Figure 3. Classification according to the thermochemical material (TCM) process.

The diffusion control step can be separated in two diffusion processes, which occur in solid-gas reactions: one from the gas to the solid surface (external diffusion), and a second from the outer surface of the solid particle to the inner part of the particle (internal diffusion) $[37,38]$.

Another limiting step could be the chemical reaction, and thus kinetics itself. There are several criteria to identify the influence of diffusion and temperature difference within the particle on the reaction rate. This should be studied for each specific reaction in order to differentiate the processes controlled by chemical reaction (thermal decomposition) and processes to be studied as its limiting step (solid-gas reaction). 


\section{Reactors Used in Solar Plants}

Table 2 is a summary of all of the available experimental reactors that have been published until September 2017, of which most work at temperatures above $1000{ }^{\circ} \mathrm{C}(1273 \mathrm{~K})$.

Sixty-eight experimental reactors have been found in the literature working at high temperatures, including 48 of them working above $1000{ }^{\circ} \mathrm{C}$. Both thermal decomposition and solid-gas chemical reaction processes are carried out in these reactors, with the chemical reaction type the being the dominant one. Most of the reactors $(81 \%)$ are part of a direct and closed system, followed by indirect systems (15\%); direct and open systems only make up 3\%. Then, when looking at the highest-level group of system configurations (direct and closed), the main observations are:

- All of the available and described reactor types are presented: entrained, stacked, and fluidized.

- The main available reactors that have been tested at the lab scale are stacked/fixed bed, $50 \%$.

- Fluidized beds are the second most reported option, with around $21 \%$.

- Stacked/rotary reactors are in third position, with $15 \%$ of the implementation within this group.

- Cyclone reactors have been implemented in all of the possible system configurations: direct/open, direct/closed, and indirect. The most available ones are in active/direct/closed system configuration.

In general, and as a summary of all of the reactor configurations listed in Table 2, the statistics of different combinations of system, reactors, and processes are presented in Table 3.

The rotary reactors, which are within the stacked bed reactors, are mainly found in the direct and closed system group, with half of them using decomposition processes, and the other half using chemical reactions. Those reactors account for around $24 \%$ of the total decomposition processes. The solar efficiencies of these decomposition processes are between $12-88 \%$, and chemical conversion varies between $30-95 \%$ in these reactors. Rotary reactors reduce radiation losses with constant temperature in the internal wall. Moreover, the movement of the particles increases the heat transfer [44].

Fluidized beds are used in reactors in direct/closed systems, with most of them using solid-gas reactions ( 13 out of 14 ). They represent $28 \%$ of the total number of reactors used for solid-gas reactions. Chemical conversions vary from less than $10 \%$ to $100 \%$. Data regarding solar efficiency is only available for three of the reactors, with values ranging between $10-15 \%$.

Fixed bed reactors, which are the most frequent type of reactors, have been used for both processes; almost $32 \%$ for thermal decomposition and $68 \%$ for solid-gas reactions. They represent $49 \%$ of the reactors used for solid-gas reactions. Chemical conversions vary from $25 \%$ to $100 \%$ for thermal decomposition and from less than $15 \%$ to $85 \%$ for solid-gas reactions (note that there is a reactor presenting a $2 \%$ chemical conversion, which uses a foam matrix, and has been discarded in this comparison [28]). Furthermore, very little data is available concerning solar efficiency, especially for direct, closed fixed bed reactors, due to the difficulties of scaling up this technology in commercial solar applications. 
Table 2. Summary of reactor configurations.

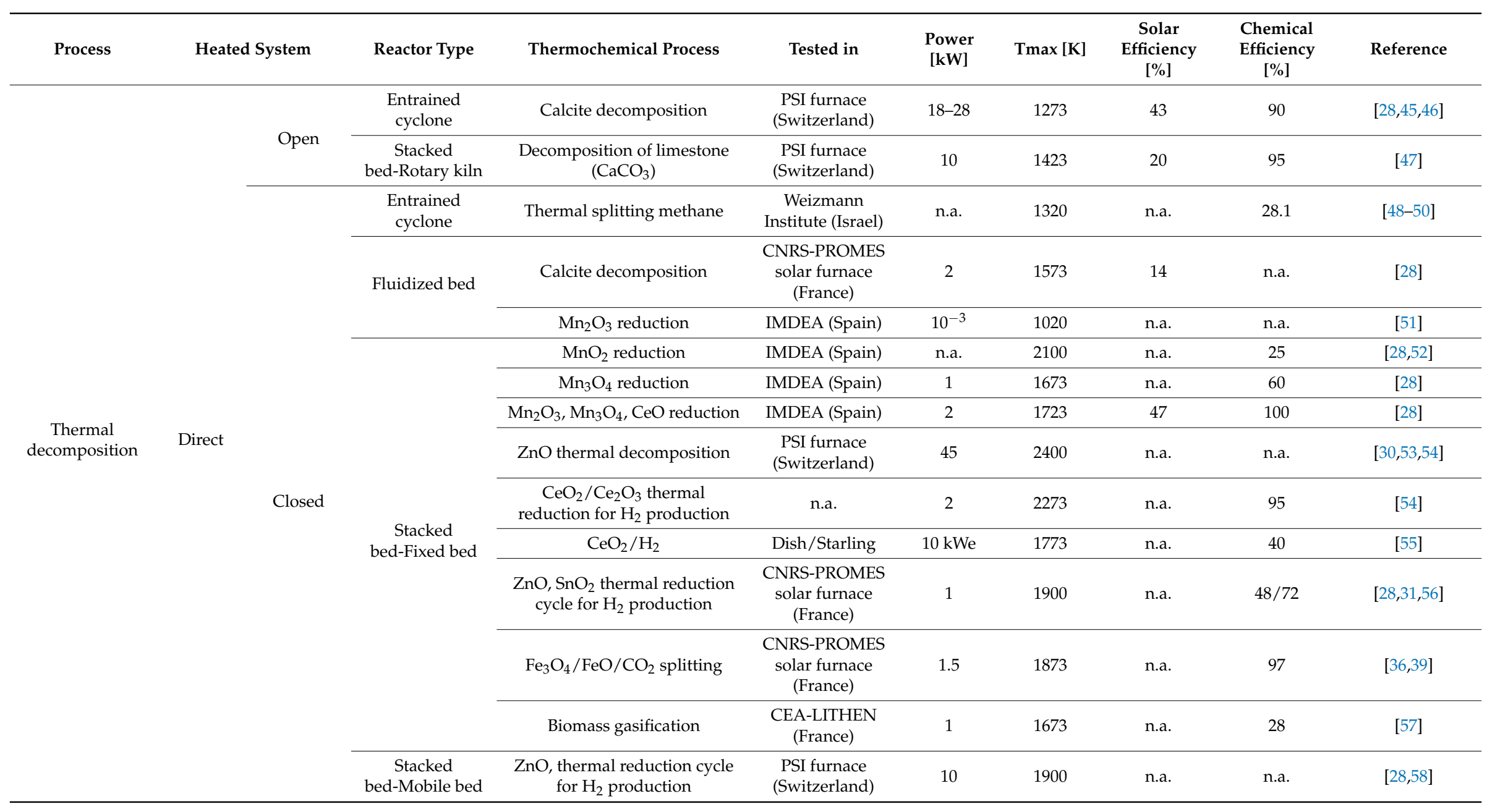


Table 2. Cont

\begin{tabular}{|c|c|c|c|c|c|c|c|c|c|c|}
\hline Process & \multicolumn{2}{|c|}{ Heated System } & Reactor Type & Thermochemical Process & Tested in & $\begin{array}{c}\text { Power } \\
{[\mathrm{kW}]}\end{array}$ & $\operatorname{Tmax}[\mathrm{K}]$ & $\begin{array}{c}\text { Solar } \\
\text { Efficiency } \\
{[\%]}\end{array}$ & $\begin{array}{c}\text { Chemical } \\
\text { Efficiency } \\
{[\%]}\end{array}$ & Reference \\
\hline & & & \multirow{5}{*}{$\begin{array}{c}\text { Stacked } \\
\text { bed-Rotary kiln }\end{array}$} & $\mathrm{ZnO}$ thermal decomposition & $\begin{array}{l}\text { PSI furnace } \\
\text { (Switzerland) }\end{array}$ & 10 & 2000 & n.a. & 35 & {$[59,60]$} \\
\hline & & & & $\mathrm{ZnO}$ thermal decomposition & $\begin{array}{l}\text { PSI furnace } \\
\text { (Switzerland) }\end{array}$ & 10 & 1900 & 12 & 95 & {$[60,61]$} \\
\hline & & & & $\mathrm{ZnO}$ thermal decomposition & $\begin{array}{l}\text { PSI furnace } \\
\text { (Switzerland) }\end{array}$ & 10 & 2136 & n.a. & 90 & {$[30,62]$} \\
\hline & & & & $\mathrm{ZnO}$ thermal decomposition & $\begin{array}{l}\text { PSI furnace } \\
\text { (Switzerland) }\end{array}$ & 15 & 2023 & n.a. & 30 & [63] \\
\hline & & & & $\mathrm{ZnO}$ thermal decomposition & $\begin{array}{l}\text { PSI furnace } \\
\text { (Switzerland) }\end{array}$ & 115 & 2000 & 0.88 & 3 & [64] \\
\hline & \multirow{2}{*}{\multicolumn{2}{|c|}{ Indirect }} & \multirow{2}{*}{$\begin{array}{c}\text { Stacked } \\
\text { bed-Fixed bed }\end{array}$} & $\mathrm{CaCO}_{3}$ lime decomposition & $\begin{array}{l}\text { PSI furnace } \\
\text { (Switzerland) }\end{array}$ & 10 & 1873 & 35 & 95 & [65] \\
\hline & & & & Wood & $\begin{array}{l}\text { CNRS-PROMES } \\
\text { solar furnace } \\
\text { (France) }\end{array}$ & 1 & 1673 & 28 & 82 & [66] \\
\hline \multirow{6}{*}{$\begin{array}{l}\text { Chemical } \\
\text { reaction }\end{array}$} & \multirow{6}{*}{\multicolumn{2}{|c|}{ Direct }} & \multirow{2}{*}{$\begin{array}{l}\text { Entrained bed } \\
\text { cyclone }\end{array}$} & $\begin{array}{l}\mathrm{ZnO} \text { reduction with } \mathrm{CH}_{4} \text { and } \\
\text { syngas production }\end{array}$ & $\begin{array}{l}\text { PSI furnace } \\
\text { (Switzerland) }\end{array}$ & 5 & 1600 & n.a. & 90 & [67] \\
\hline & & & & Steam gasification of petcoke & $\begin{array}{l}\text { PSI furnace } \\
\text { (Switzerland) }\end{array}$ & 5 & 1818 & 9 & 87 & {$[67,68]$} \\
\hline & & & \multirow{4}{*}{ Fluidized bed } & $\begin{array}{l}\mathrm{ZnO} \text { reduction with } \mathrm{CH}_{4} \text { and } \\
\text { syngas production }\end{array}$ & $\begin{array}{l}\text { PSI furnace } \\
\text { (Switzerland) }\end{array}$ & 2.9 & 1373 & n.a. & 43 & [69] \\
\hline & & & & $\begin{array}{c}\mathrm{CaO} / \mathrm{CaCO}_{3} \text {, atmospheric } \mathrm{CO}_{2} \\
\text { capture }\end{array}$ & $\begin{array}{l}\text { PSI furnace } \\
\text { (Switzerland) }\end{array}$ & n.a. & 1150 & n.a. & 71 & [70] \\
\hline & & & & $\begin{array}{l}\mathrm{NiFe}_{2} \mathrm{O}_{4} / \mathrm{m}-\mathrm{ZnO} \\
\text { thermochemical cycle } / \mathrm{H}_{2} \\
\text { production }\end{array}$ & $\begin{array}{l}\text { Niigata } \\
\text { University solar } \\
\text { simulator } \\
\text { (Japan) }\end{array}$ & 2 & 1473 & n.a. & 45 & [71-73] \\
\hline & & & & Steam gasification of charcoal & $\begin{array}{l}\text { CNRS-PROMES } \\
\text { solar furnace } \\
\text { (France) }\end{array}$ & 2 & 1773 & 10 & 100 & {$[29,74,75]$} \\
\hline
\end{tabular}


Table 2. Cont.

\begin{tabular}{|c|c|c|c|c|c|c|c|c|c|}
\hline Process & Heated System & Reactor Type & Thermochemical Process & Tested in & $\begin{array}{c}\text { Power } \\
{[\mathrm{kW}]}\end{array}$ & $\operatorname{Tmax}[K]$ & $\begin{array}{c}\text { Solar } \\
\text { Efficiency } \\
{[\%]}\end{array}$ & $\begin{array}{c}\text { Chemical } \\
\text { Efficiency } \\
{[\%]}\end{array}$ & Reference \\
\hline & & & Steam gasification of charcoal & $\begin{array}{l}\text { University of } \\
\text { Minnesota solar } \\
\text { furnace (USA) }\end{array}$ & 6 & 1600 & n.a. & 100 & {$[29,76]$} \\
\hline & & & $\mathrm{CeO}_{2}$ water splitting & $\begin{array}{l}\text { Center for } \\
\text { Transdisciplinary } \\
\text { research }\end{array}$ & 7 & 1173 & n.a. & n.a. & [77] \\
\hline & & & $\mathrm{CeO}_{2}$ water splitting & $\begin{array}{l}\text { ETH Zurich } \\
\text { (Switzerland) }\end{array}$ & $2.8-3.8$ & 1873 & n.a. & n.a. & [78] \\
\hline & & & $\mathrm{CO}+\mathrm{H}_{2} \mathrm{O}$ & $\begin{array}{l}\text { Center for } \\
\text { Transdisciplinary } \\
\text { research (Japan) }\end{array}$ & 5 & 2073 & 15 & $<10$ & [79] \\
\hline & & & Sr-doped $+\mathrm{CaMnO}_{3}$ & $\begin{array}{l}\text { Colorado School } \\
\text { of Mines (USA) }\end{array}$ & n.a. & 1273 & n.a. & n.a. & [80] \\
\hline & & & $\mathrm{Fe}_{2} \mathrm{O}_{3}$ water splitting & $\begin{array}{c}\text { Niigata } \\
\text { University solar } \\
\text { simulator } \\
\text { (Japan) } \\
\end{array}$ & 30 & 1473 & n.a. & n.a. & [81] \\
\hline & & & $\mathrm{CaO} / \mathrm{CaCO}_{3}$ & $\begin{array}{l}\text { University of } \\
\text { Sevilla (Spain) }\end{array}$ & n.a. & 1100 & n.a. & 15 & [82] \\
\hline & & & Metal oxide reduction & $\begin{array}{l}\text { DLR solar } \\
\text { furnace } \\
\text { (Germany) }\end{array}$ & n.a. & 1073 & n.a. & n.a. & [83] \\
\hline & & & Calcium looping & IRC (Italy) & 3 & 1023 & n.a. & n.a. & [84] \\
\hline & & \multirow{4}{*}{$\begin{array}{c}\text { Stacked } \\
\text { bed-Fixed bed }\end{array}$} & $\begin{array}{c}\mathrm{Fe}_{2} \mathrm{O}_{3}, \mathrm{Fe}_{3} \mathrm{O}_{4}, \mathrm{Mn}_{3} \mathrm{O}_{4} \\
\text { reduction }\end{array}$ & $\begin{array}{l}\text { PSI furnace } \\
\text { (Switzerland) }\end{array}$ & n.a. & 2100 & n.a. & 85 & {$[28,50]$} \\
\hline & & & $\begin{array}{c}\mathrm{CeO}_{2} \mathrm{CO}_{2}-\mathrm{H}_{2} \mathrm{O} \text { splitting } \\
\text { (foam) }\end{array}$ & $\begin{array}{l}\text { PSI furnace } \\
\text { (Switzerland) }\end{array}$ & 2 & 1913 & $0.7-0.8$ & 2 & {$[28,30,31,85-87]$} \\
\hline & & & $\begin{array}{l}\text { Ferrite for } \mathrm{H}_{2} \text { production } \\
\quad \text { (honeycombs) }\end{array}$ & $\begin{array}{l}\text { Plataforma Solar } \\
\text { de Almeria } \\
\text { (Spain) }\end{array}$ & 100 & 1473 & n.a. & 30 & {$[31,86-89]$} \\
\hline & & & $\begin{array}{l}\text { Syngas production via } \\
\mathrm{CH}_{4}-\mathrm{CO}_{2} \text { (foam) }\end{array}$ & SANDIA (USA) & 97 & 1473 & n.a. & 54 & {$[31,90]$} \\
\hline
\end{tabular}


Table 2. Cont.

\begin{tabular}{|c|c|c|c|c|c|c|c|c|c|}
\hline Process & Heated System & Reactor Type & Thermochemical Process & Tested in & $\begin{array}{c}\text { Power } \\
{[\mathrm{kW}]}\end{array}$ & $\operatorname{Tmax}[K]$ & $\begin{array}{c}\text { Solar } \\
\text { Efficiency } \\
{[\%]}\end{array}$ & $\begin{array}{c}\text { Chemical } \\
\text { Efficiency } \\
{[\%]}\end{array}$ & Reference \\
\hline & & & $\begin{array}{c}\mathrm{NiFe}_{2} \mathrm{O}_{4} / \mathrm{m}-\mathrm{ZrO}_{2} \text {-coated for } \\
\mathrm{H}_{2} \text { production (foam) }\end{array}$ & $\begin{array}{c}\text { Niigata } \\
\text { University solar } \\
\text { simulator } \\
\text { (Japan) }\end{array}$ & $0.7(2)$ & 1773 & n.a. & 60 & {$[31,72,91]$} \\
\hline & & & $\mathrm{CeO}-\mathrm{CO}_{2}$ splitting & $\begin{array}{c}\text { University of } \\
\text { Minnesota solar } \\
\text { furnace (USA) }\end{array}$ & 4.4 & 1847 & n.a. & 72 & [92] \\
\hline & & & $\mathrm{CO}_{2}$ splitting redox & $\begin{array}{l}\text { ETH Zurich } \\
\text { (Switzerland) }\end{array}$ & 3.8 & 1873 & n.a. & $<15$ & [93] \\
\hline & & & $\mathrm{Co}_{3} \mathrm{O}_{4} / \mathrm{CoO}$ & $\begin{array}{l}\text { DLR solar } \\
\text { furnace } \\
\text { (Germany) }\end{array}$ & n.a. & 1273 & 65 & n.a. & [94] \\
\hline & & & $\mathrm{CaO} / \mathrm{Ca}(\mathrm{OH})_{2}$ & $\begin{array}{l}\text { DLR solar } \\
\text { furnace } \\
\text { (Germany) }\end{array}$ & n.a. & 773 & 94 & n.a. & [95] \\
\hline & & & $\mathrm{CaO} / \mathrm{Ca}(\mathrm{OH})_{2}$ & $\begin{array}{l}\text { CEA-LITHEN } \\
\text { (France) }\end{array}$ & 5.5 & 773 & n.a. & n.a. & [96] \\
\hline & & & $\mathrm{NH}_{3} / \mathrm{N}_{2}$ & $\begin{array}{l}\text { IT Power } \\
\text { (Australia) }\end{array}$ & 5 & 948 & n.a. & n.a. & [97] \\
\hline & & & $\mathrm{CH}_{4}$ & $\begin{array}{l}\text { Guangdong } \\
\text { Yudean Xinhui } \\
\text { Generation } \\
\text { (China) }\end{array}$ & n.a. & 800 & 50 & 47.2 & [98] \\
\hline & & & $\mathrm{CH}_{4}$ & $\begin{array}{l}\text { Sun Yat-Sen } \\
\text { University } \\
\text { (China) }\end{array}$ & n.a. & 563 & n.a. & n.a. & [99] \\
\hline & & & $\mathrm{CH}_{4}$ & n.a. & n.a. & 948 & 55 & 25 & [100] \\
\hline & & & $\mathrm{CeO}_{2}$ water splitting & CIEMAT (Spain) & 57.5 & 1473 & n.a. & n.a. & [101] \\
\hline & & & $\mathrm{CeO}_{2}-\mathrm{CO}_{2}$ splitting & $\begin{array}{l}\text { CNRS-PROMES } \\
\text { solar furnace } \\
\text { (France) }\end{array}$ & n.a. & 1273 & n.a. & n.a. & [102] \\
\hline & & & n.a. & n.a. & n.a. & 1073 & 99 & n.a. & [103] \\
\hline
\end{tabular}


Table 2. Cont.

\begin{tabular}{|c|c|c|c|c|c|c|c|c|c|}
\hline Process & Heated System & Reactor Type & Thermochemical Process & Tested in & $\begin{array}{c}\text { Power } \\
{[k W]}\end{array}$ & $\operatorname{Tmax}[K]$ & $\begin{array}{c}\text { Solar } \\
\text { Efficiency } \\
{[\%]}\end{array}$ & $\begin{array}{c}\text { Chemical } \\
\text { Efficiency } \\
{[\%]}\end{array}$ & Reference \\
\hline & & \multirow{5}{*}{ Rotary kiln } & $\begin{array}{c}\mathrm{CoO} / \mathrm{Co}_{3} \mathrm{O}_{4} \text { thermochemical } \\
\text { heat storage }\end{array}$ & $\begin{array}{l}\text { DLR solar } \\
\text { furnace } \\
\text { (Germany) }\end{array}$ & 10 & 1173 & n.a. & 70 & {$[37,104]$} \\
\hline & & & $\begin{array}{c}\mathrm{CuO} / \mathrm{CuO}_{2} \text { thermochemical } \\
\text { reaction }\end{array}$ & $\begin{array}{l}\text { IER-UNAM } \\
\text { (Mexico) }\end{array}$ & 28.5 & n.a. & n.a. & 80 & [105] \\
\hline & & & $\begin{array}{l}\mathrm{CuO} / \mathrm{CuO}_{2} \text { thermochemical } \\
\text { reaction }\end{array}$ & $\begin{array}{l}\text { University of } \\
\text { Antofagasta } \\
\text { (Chile) }\end{array}$ & n.a. & 1153 & n.a. & 80 & [106] \\
\hline & & & $\mathrm{Mn}_{2} \mathrm{O}_{3} / \mathrm{Mn}_{3} \mathrm{O}_{4}$ & IMDEA (Spain) & 10 & 1700 & 15 & 85 & [106] \\
\hline & & & $\mathrm{SrBr}_{2} \cdot \mathrm{H}_{2} \mathrm{O} / \mathrm{SrBr}_{6} \cdot 6 \mathrm{H}_{2} \mathrm{O}$ & $\begin{array}{l}\text { CNRS-PROMES } \\
\text { solar furnace } \\
\text { (France) }\end{array}$ & $300-600$ & 353 & n.a. & n.a. & [107] \\
\hline & & $\begin{array}{c}\text { Stacked } \\
\text { bed-Mobile bed }\end{array}$ & $\mathrm{ZnO}$ & $\begin{array}{l}\text { ETH Zurich } \\
\text { (Switzerland) }\end{array}$ & 10 & 1446 & 14 & $<12.4$ & [108] \\
\hline & Direct/Indirect & $\begin{array}{l}\text { CONTISOL } \\
\text { configuration }\end{array}$ & $\mathrm{CH}_{4}$ & $\begin{array}{l}\text { DLR solar } \\
\text { furnace } \\
\text { (Germany) }\end{array}$ & 6 & 1223 & n.a. & n.a. & [109] \\
\hline & \multirow{5}{*}{ Indirect } & $\begin{array}{l}\text { Entrained bed } \\
\text { cyclone }\end{array}$ & Steam gasification of charcoal & $\begin{array}{l}\text { PSI solar } \\
\text { furnace } \\
\text { (Switzerland) }\end{array}$ & 3 & 1425 & 1.53 & 26 & {$[110,111]$} \\
\hline & & \multirow{4}{*}{$\begin{array}{c}\text { Stacked } \\
\text { bed-Fixed bed }\end{array}$} & Steam gasification of charcoal & $\begin{array}{c}\text { PSI solar } \\
\text { furnace } \\
\text { (Switzerland) }\end{array}$ & 5 & 1440 & 29 & n.a. & {$[29,112,113]$} \\
\hline & & & Steam gasification of charcoal & $\begin{array}{l}\text { PSI solar } \\
\text { furnace } \\
\text { (Switzerland) }\end{array}$ & 8 & 1490 & 28 & n.a. & {$[29,114]$} \\
\hline & & & $\mathrm{CaO} / \mathrm{Ca}(\mathrm{OH})_{2}$ & $\begin{array}{l}\text { DLR solar } \\
\text { furnace } \\
\text { (Germany) }\end{array}$ & 10 & 823 & 90 & n.a. & [115] \\
\hline & & & $\mathrm{Mn}_{2} \mathrm{O}_{3}$ and $\mathrm{Al}_{2} \mathrm{O}_{3}$ & $\begin{array}{l}\text { IMDEA solar } \\
\text { furnace (Spain) }\end{array}$ & 2.1 & 1673 & 25.4 & 41.6 & [116] \\
\hline
\end{tabular}


Table 2. Cont

\begin{tabular}{|c|c|c|c|c|c|c|c|c|c|}
\hline Process & Heated System & Reactor Type & Thermochemical Process & Tested in & $\begin{array}{c}\text { Power } \\
{[\mathrm{kW}]}\end{array}$ & $\operatorname{Tmax}[K]$ & $\begin{array}{c}\text { Solar } \\
\text { Efficiency } \\
{[\%]}\end{array}$ & $\begin{array}{c}\text { Chemical } \\
\text { Efficiency } \\
{[\%]}\end{array}$ & Reference \\
\hline & & & $\mathrm{CaO} / \mathrm{Ca}(\mathrm{OH})_{2}$ & $\begin{array}{l}\text { DLR solar } \\
\text { furnace } \\
\text { (Germany) }\end{array}$ & 2 & 873 & 95 & n.a. & [117] \\
\hline & & & $\mathrm{CaO} / \mathrm{Ca}(\mathrm{OH})_{2}$ & IET (China) & 2 & 613 & n.a. & n.a. & [118] \\
\hline & & $\begin{array}{c}\text { Stacked } \\
\text { bed-Mobile bed }\end{array}$ & $\mathrm{ZnO}$ reduction with carbon & $\begin{array}{c}\text { PSI solar } \\
\text { furnace } \\
\text { (Switzerland) }\end{array}$ & 5 & 1500 & 15 & 25 & {$[119,120]$} \\
\hline
\end{tabular}


Table 3. Statistics of systems, reactors, and processes undergone.

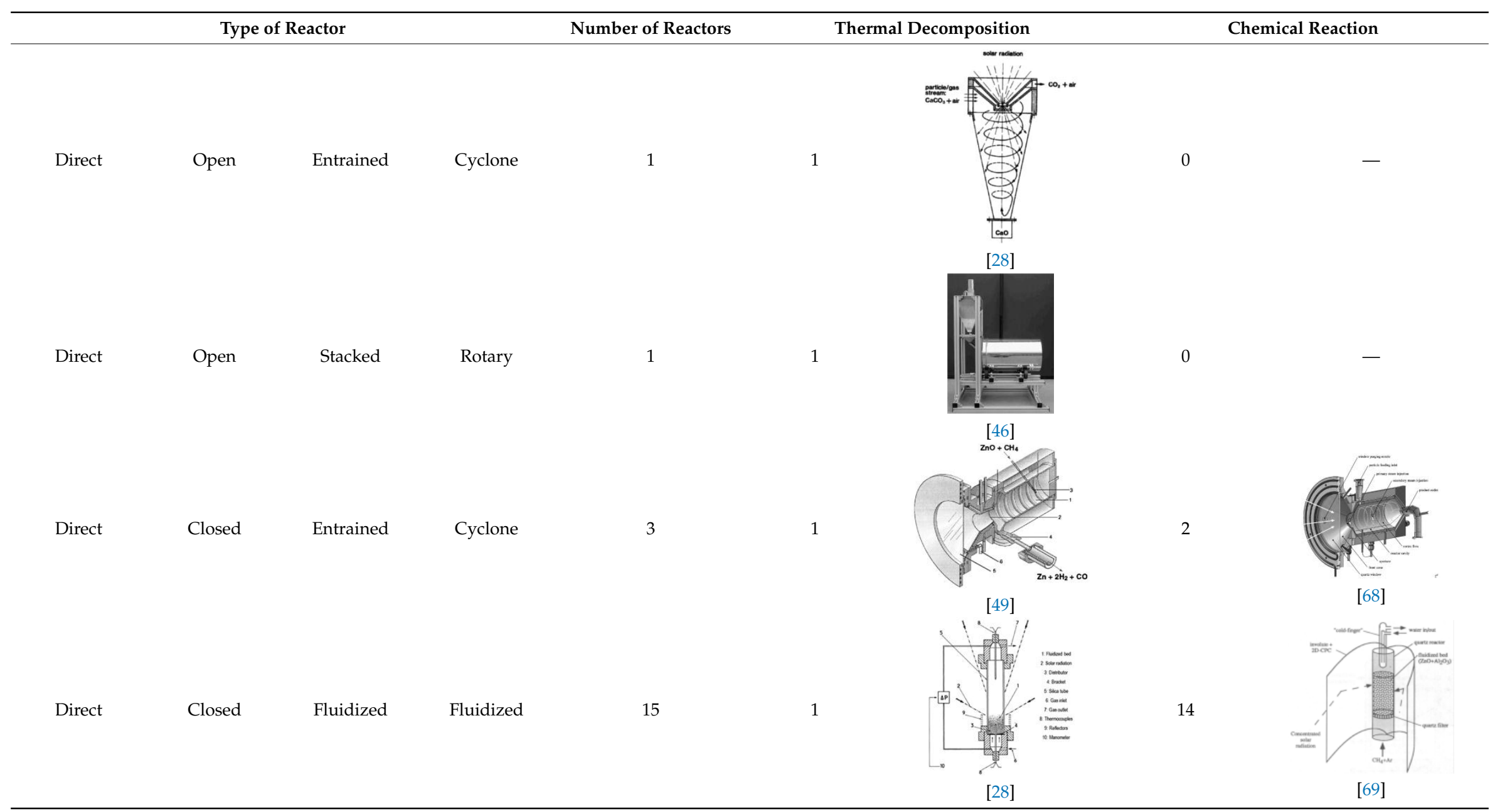


Table 3. Cont.

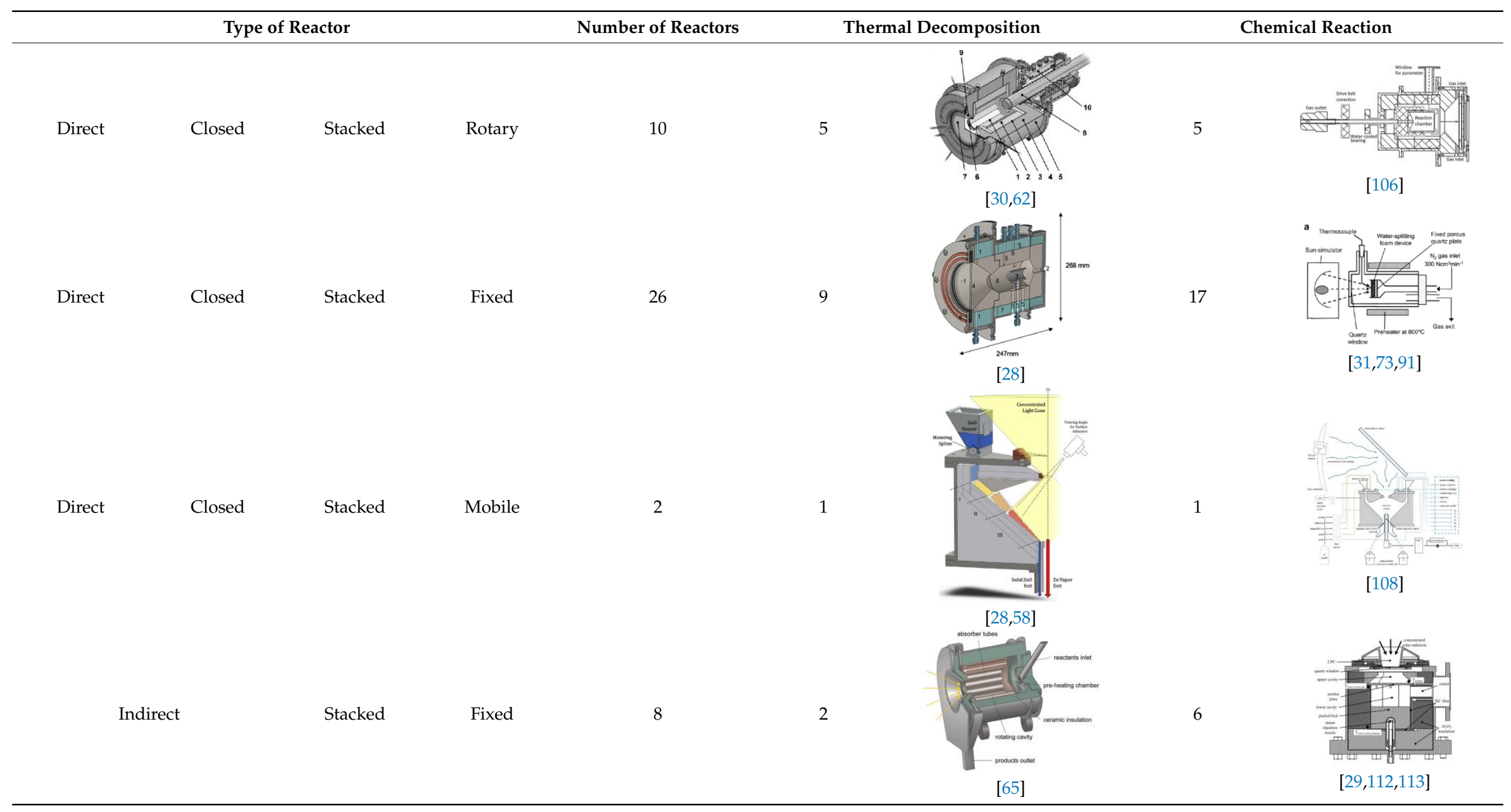


Table 3. Cont

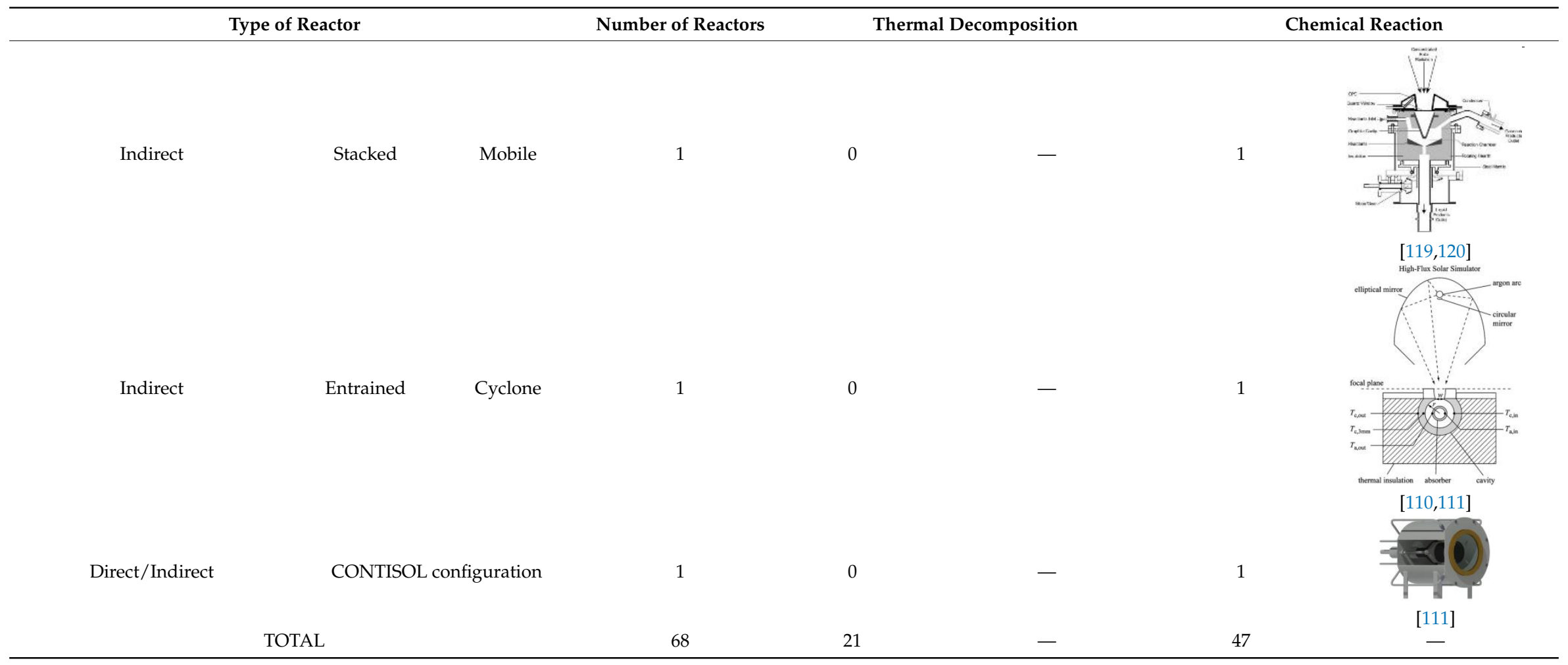




\section{Conclusions}

The analysis of the available literature shows that there will not be a single reactor configuration to be applied for solar thermochemical process. The diversity of the detailed problems shows that the technology is still in low technology readiness level (TRL) - less than five-and significant research and development are still demanded. The design and optimization of the reactor to be used must be defined by the chemistry of the reaction, the dominant transfer mechanisms, and the compatibility of the materials. Moreover, all of this must be designed with ambitious solar efficiency objectives in order to minimize the cost of the solar field, which continues to be one of the limitations in the cost savings of CSP.

Reactors implemented in direct systems are by far the most studied ones. A very high percentage of both solid-gas reactions and thermal decompositions, around $81 \%$ of the total systems analyzed, consists of a direct and closed system configuration. Within this configuration, the majority of all of the processes-around $69 \%$ - take place in stacked reactors, and within this reactor type, fixed bed reactors are preferred (68\%). The direct configuration has a significant lower cost than an indirect system. Additionally, the closed configuration is mandatory at high temperature to increase the solar efficiency in the reactor receiver.

Fixed beds are being used to undergo both processes; they are more used for chemical reactions and show better chemical conversion in thermal decomposition processes. However, their use in solar applications is at a very preliminary stage of application. The control of the temperature in the irradiated solid, the uniformity of the flux map, the effect of the diffusion mechanism, and the scalability of the processes makes their applicability difficult.

Fluidized beds are preferred for solid-gas reactions, and are known to increase two phases (gas and solid) contact and thus heat and mass transfer. Therefore, they are recommended for solid-gas reactions, whose limiting step is diffusion, which is either external or internal. Nevertheless, complexity in design, increase in the self-consumption, and the erosion/wear of internal components are big drawbacks to overcome.

Solar efficiencies up to now have been very low. Those values cannot be compared, since very little data is found in the published papers. The state-of-the-art showed $50 \%$ as the maximum solid receiver efficiency achieved so far; however, a value higher than $80 \%$ is required to make this solar system economically feasible.

Chemical conversions are acceptable in some specific cases; these are mainly fluidized bed reactors for solid-gas chemical reactions, and fixed bed reactors and rotary reactors for thermal decompositions.

Most of the problems found when working experimentally with these reactors are due to material resistance and low chemical conversions due to an insufficient radiation power or bad use of it. Important operational and design parameters when working with a CSP reactor are the geometry of the reactor, which needs to be optimized, the preheating of the inlet gas, the reactor configuration (continuous or batch), and re-radiation losses.

Author Contributions: Conceptualization, L.F.C. and C.P.; Methodology, A.I.F. and G.Z.; Formal Analysis, G.Z. and A.S.; Investigation, C.B. and A.S.; Writing-Original Draft Preparation, G.Z., A.S. and C.B.; Writing-Review \& Editing, L.F.C. and C.P.; Supervision, L.F.C. and A.I.F.

Funding: The work is partially funded by the Spanish government (ENE2015-64117-C5-1-R (MINECO/FEDER) and ENE2015-64117-C5-2-R (MINECO/FEDER)). The authors would like to thank the Catalan Government for the quality accreditation given to their research groups GREA (2017 SGR 1537) and DIOPMA (2017 SGR 118). GREA and DIOPMA are certified agents TECNIO in the category of technology developers from the Government of Catalonia. Dr. Aran Solé would like to thank Ministerio de Economía y Competitividad de España for Grant Juan de la Cierva, FJCI-2015-25741.

Conflicts of Interest: The authors declare no conflict of interest. 


\section{References}

1. Price, H.; Lüpfert, E.; Kearney, D.; Zarza, E.; Cohen, G.; Gee, R.; Mahoney, R. Advances in parabolic trough solar power technology. J. Sol. Energy Eng. 2002, 124, 109-125. [CrossRef]

2. del Rio, P.; Peñasco, C.; Mir-Artiques, P. An overview of drivers and barriers to concentrated solar power in the European Union. Renew. Sustain. Energy Rev. 2018, 81, 1019-1029. [CrossRef]

3. REN21. Renewables 2017 Global Status Report; REN21: Paris, French, 2017.

4. IRENA. Renewable Energy Technologies: Cost Analysis Series-Concentrating Solar Power; IRENA: Abu Dhabi, United Arab Emirates, 2012. Available online: https: / www.irena.org/documentdownloads / publications / re_technologies_cost_analysis-csp.pdf (accessed on 4 September 2018).

5. REmap 2030. A Renewable Energy Roadmap; IRENA: Abu Dhabi, United Arab Emirates, 2014.

6. IRENA. REmap: Roadmap for A Renewable Energy Future, 2016th ed.; International Renewable Energy Agency (IRENA): Abu Dhabi, United Arab Emirates, 2016.

7. IEA. World Energy Outlook; IEA publications: París, France, 2012. Available online: https:/ / webstore.iea.org/ world-energy-outlook-2012-2 (accessed on 4 September 2018).

8. IEA. Energy Technology Perspectives; IEA publications: París, France, 2014. Available online: https://webstore. iea.org/energy-technology-perspectives-2014 (accessed on 4 September 2018).

9. IEA. STE Technology Roadmap; IEA publications: París, France, 2014.

10. ESTELA. Everything You Always Wanted to Know about Solar Thermal Electricity (STE/CSP) but just never Asked; ESTELA: Brussels, Belgium, 2014.

11. Müller-Steinhagen, H.; Trieb, F. Concentrating solar power: A review of the technology. Ingenia Inf. QR Acad. Eng. 2004, 18, 43-50.

12. Romero, M.; González-Aguilar, J. Solar thermal CSP technology. Wiley Interdiscip. Energy Environ. 2014, 3, 42-59. [CrossRef]

13. Kuravi, S.; Trahan, J.; Goswami, D.Y.; Rahman, M.M.; Stefanakos, E.K. Thermal energy storage technologies and systems for concentrating solar power plants. Prog. Energy Combust. Sci. 2013, 39, 285-319. [CrossRef]

14. Pelay, U.; Luo, L.; Fan, Y.; Stitou, D.; Rood, M. Thermal energy storage for concentrated solar power plants. Renew. Sustain. Energy Rev. 2017, 79, 82-100. [CrossRef]

15. Prieto, C.; Cooper, P.; Fernandez, A.I.; Cabeza, L.F. Review of technology: Thermochemical energy storage for concentrated solar power plants. Renew. Sustain. Energy Rev. 2016, 60, 909-929. [CrossRef]

16. Gil, A.; Medrano, M.; Martorell, I.; Lázaro, A.; Dolado, P.; Zalba, B.; Cabeza, L.F. State of the art on high temperature thermal energy storage for power generation. Part 1 -concepts, materials and modellization. Renew. Sustain. Energy Rev. 2010, 14, 31-55. [CrossRef]

17. Medrano, M.; Gil, A.; Martorell, I.; Potau, X.; Cabeza, L.F. State of the art on high-temperature thermal energy storage for power generation. Part 2-Case studies. Renew. Sustain. Energy Rev. 2010, 14, 56-72. [CrossRef]

18. Liu, M.; Tay, N.H.S.; Bell, S.; Belusko, M.; Jacob, R.; Will, G.; Saman, W.; Bruno, F. Review on concentrating solar power plants and new developments in high temperature thermal energy storage technologies. Renew. Sustain. Energy Rev. 2016, 53, 1311-1432. [CrossRef]

19. González-Roubaud, E.; Pérez-Osorio, D.; Prieto, C. Review of commercial thermal energy storage in concentrated solar power plants: Steam vs. molten salts. Renew. Sustain. Energy Rev. 2017, 80, 133-148. [CrossRef]

20. Dowling, A.W.; Zheng, T.; Zavala, V.M. Economic assessment of concentrated solar power technologies: A review. Renew. Sustain. Energy Rev. 2017, 72, 1019-1032. [CrossRef]

21. Gasia, J.; Miró, L.; Cabeza, L.F. Review on system and materials requirements for high temperature thermal energy storage. Part 1: General requirements. Renew. Sustain. Energy Rev. 2017, 75, 1320-1338. [CrossRef]

22. Liu, M.; Saman, W.; Bruno, F. Review on storage materials and thermal performance enhancement techniques for high temperature phase change thermal storage systems. Renew. Sustain. Energy Rev. 2012, 16, 2118-2132. [CrossRef]

23. Cárdenas, B.; León, N. High temperature latent heat thermal energy storage: Phase change materials, design considerations and performance enhancement techniques. Renew. Sustain. Energy Rev. 2013, 27, 724-737. [CrossRef]

24. Jacob, R.; Bruno, F. Review on shell materials used in the encapsulation of phase change materials for high temperature thermal energy storage. Renew. Sustain. Energy Rev. 2015, 48, 79-87. [CrossRef] 
25. Xu, B.; Li, P.; Chan, C. Application of phase change materials for thermal energy storage in concentrated solar thermal power plants: A review to recent developments. Appl. Energy 2015, 160, 286-307. [CrossRef]

26. Felderhoff, M.; Urbanczyk, R.; Peil, S. Thermochemical heat storage for high temperature applications-A review. Green 2013, 3, 113-123. [CrossRef]

27. Pardo, P.; Deydier, D.; Anzionnaz-Minvielle, Z.; Rouge, S.; Cabassud, M.; Cognet, P. A review on high temperature thermochemical heat energy storage. Renew. Sustain. Energy Rev. 2014, 32, 591-610. [CrossRef]

28. Alonso, E.; Romero, M. Review of experimental investigation on directly irradiated particles solar reactors. Renew. Sustain. Energy Rev. 2015, 41, 53-67. [CrossRef]

29. Puig-Arnavat, M.; Tora, E.A.; Bruno, J.C.; Coronas, A. State of the art on reactor designs for solar gasification of carbonaceous feedstock. Sol. Energy 2013, 97, 67-84. [CrossRef]

30. Romero, M.; Steinfeld, A. Concentrating solar thermal power and thermochemical fuels. Energy Environ. Sci. 2012, 5, 9234. [CrossRef]

31. Agrafiotis, C.; Roeb, M.; Sattler, C. A review on solar thermal syngas production via redox pair-based water/carbon dioxide splitting thermochemical cycles. Renew. Sustain. Energy Rev. 2015, 42, 254-285. [CrossRef]

32. Agrafiotis, C.; von Storch, H.; Roeb, M.; Sattler, C. Solar thermal reforming of methane feedstocks for hydrogen and syngas production-A review. Renew. Sustain. Energy Rev. 2014, 29, 656-682. [CrossRef]

33. Scheffe, J.R.; Steinfeld, A. Oxygen exchange materials for solar thermochemical splitting of $\mathrm{H}_{2} \mathrm{O}$ and $\mathrm{CO}_{2}$ : A review. Mater. Today 2014, 17, 341-348. [CrossRef]

34. Steinfeld, A.; Palumbo, R. Solar Thermochemical Process Technology. Encycl. Phys. Sci. Technol. 2001, 15, 237-256.

35. Abanades, S.; Charvin, P.; Flamant, G.; Neveu, P. Screening of water-splitting thermochemical cycles potentially attractive for hydrogen production by concentrated solar energy. Energy 2006, 31, 2805-2822. [CrossRef]

36. Graves, C.; Ebbesen, S.D.; Mogensen, M.; Lackner, K.S. Sustainable hydrocarbon fuels by recycling $\mathrm{CO}_{2}$ and $\mathrm{H} 2 \mathrm{O}$ with renewable or nuclear energy. Renew. Sustain. Energy Rev. 2011, 15, 1-23. [CrossRef]

37. Neises, M.; Tescari, S.; de Oliveira, L.; Roeb, M.; Sattler, C.; Wong, B. Solar-heated rotary kiln for thermochemical energy storage. Sol. Energy 2012, 86, 3040-3048. [CrossRef]

38. Villermaux, J. Les reacteurs chimiques solaires. Entropie Paris 1979, 15, 25-31.

39. Trambouze, P.; van Landeghem, H.; Wauquier, J.P. Chemical Reactors: Design, Engineering, Operation; Gulf Publishing Company: Paris, French, 1988.

40. Coulson, J.M.; Richardson, J.F. Chemical Engineering; Butterworth-Heinemann: Oxford, UK, 1994.

41. Solé, A.; Martorell, I.; Cabeza, L.F. State of the art on gas-solid thermochemical energy storage systems and reactors for building applications. Renew. Sustain. Energy Rev. 2015, 47, 386-398. [CrossRef]

42. Ho, C.K. Advances in central receivers for concentrating solar applications. Sol. Energy 2017, 152, $38-56$. [CrossRef]

43. Koepf, E.; Alxneit, I.; Wieckert, C.; Meier, A. A review of high temperature solar driven reactor technology: 25 years of experience in research and development at the Paul Scherrer Institute. Appl. Energy 2017, 188, 620-651. [CrossRef]

44. Tescari, S.; Agrafiotis, C.; Breuer, S.; de Oliveira, L.; Puttkamer, M.N.; Roeb, M.; Sattler, C. Thermochemical Solar Energy Storage Via Redox Oxides: Materials and Reactor/Heat Exchanger Concepts. Energy Procedia 2014, 49, 1034-1043. [CrossRef]

45. Imhof, A. The cyclone reactor-an atmospheric open solar reactor. Sol. Energy Mater. 1991, $24,733-741$. [CrossRef]

46. Meier, A.; Bonaldi, E.; Cella, G.M.; Lipinski, W.; Wuillemin, D.; Palumbo, R. Design and experimental investigation of a horizontal rotary reactor for the solar thermal production of lime. Energy 2004, 29, 811-821. [CrossRef]

47. Kogan, M. Production of hydrogen and carbon by solar thermal methane splitting. I. The unseeded reactor. Int. J. Hydrog. Energy 2008, 28, 1187-1198. [CrossRef]

48. Kogan, A. Production of hydrogen and carbon by solar thermal methane splitting. II. Room temperature simulation tests of seeded solar reactor. Int. J. Hydrog. Energy 2004, 29, 1227-1236. [CrossRef]

49. Hirsch, D. Solar hydrogen production by thermal decomposition of natural gas using a vortex-flow reactor. Int. J. Hydrog. Energy 2004, 29, 47-55. [CrossRef] 
50. Frey, T.; Guesdon, C.; Sturzenegger, M. Kinetics on a second scale at temperatures up to $2300 \mathrm{~K}-\mathrm{The}$ reduction of manganese oxide in a solar furnace. J. Am. Ceram. Soc. 2005, 88, 3249-3252. [CrossRef]

51. de Miguel, S.Á.; Gonzalez-Aguilar, J.; Romero, M. 100-Wh multi-purpuse particle reactor for thermochemical heat storage in concentrating solar power plants. Energy Procedia 2014, 49, 676-683. [CrossRef]

52. Möller, S.; Palumbo, R. Solar thermal decomposition kinetics of ZnO in the temperature range 1950-2450 K. Chem. Eng. Sci. 2001, 56, 4505-4515. [CrossRef]

53. Keunecke, M.; Meier, A.; Palumbo, R. Solar thermal decomposition of zinc oxide: An initial investigation of the recombination reaction in the temperature range 1100-1250 K. Chem. Eng. Sci. 2004, 59, 2695-2704. [CrossRef]

54. Abanades, S.; Flamant, G. Thermochemical hydrogen production from a two-step solar-driven water-splitting cycle based on cerium oxides. Sol. Energy 2006, 80, 1611-1623. [CrossRef]

55. Binotti, M.; di Marcoberardino, G.; Biassoni, M.; Manzolini, G. Solar hydrogen production with cerium oxides thermochemical cycle. AIP Conf. Proc. 2017, 1850, 100002.

56. Chambon, M.; Abanades, S.; Flamant, G. Thermal dissociation of compressed $\mathrm{ZnO}$ and SnO2 powders in a moving-front solar thermochemical reactor. AIChE J. 2011, 57, 2264-2273. [CrossRef]

57. Bellouard, Q.; Abanades, S.; Rodat, S.; Dupassieux, N. A high temperature drop-tube and packed-bed solar reactor for continuous biomass gasification. AIP Conf. Proc. 2017, 1850, 100001.

58. Koepf, E.; Advani, S.G.; Steinfeld, A.; Prasad, A.K. A novel beam-down, gravity-fed, solar thermochemical receiver/reactor for direct solid particle decomposition: Design, modeling, and experimentation. Int. J. Hydrog. Energy 2012, 37, 16871-16887. [CrossRef]

59. Haueter, P.; Moeller, S.; Palumbo, R.; Steinfeld, A. The production of zinc by thermal dissociation of zinc oxide - Solar chemical reactor design. Sol. Energy 1999, 67, 161-167. [CrossRef]

60. Müller, R.; Haeberling, P.; Palumbo, R.D. Further advances toward the development of a direct heating solar thermal chemical reactor for the thermal dissociation of $\mathrm{ZnO}(\mathrm{s})$. Sol. Energy 2006, 80, 500-511. [CrossRef]

61. Müller, R.; Steinfeld, A. Band-approximated radiative heat transfer analysis of a solar chemical reactor for the thermal dissociation of zinc oxide. Sol. Energy 2007, 81, 1285-1294. [CrossRef]

62. Schunk, L.O.; Lipiński, W.; Steinfeld, A. Heat transfer model of a solar receiver-reactor for the thermal dissociation of ZnO-Experimental validation at $10 \mathrm{~kW}$ and scale-up to $1 \mathrm{MW}$. Chem. Eng. J. 2009, 150, 502-508. [CrossRef]

63. Koepf, E.; Villasmil, W.; Meier, A. High temperature flow visualization and aerodynamic window protection of a 100-kWth solar thermochemical receiver-reactor for ZnO dissociation. Energy Procedia 2015, 69, 1780-1789. [CrossRef]

64. Koepf, E.; Villasmil, W.; Meier, A. Pilot-scale solar reactor operation and characterization for fuel production via the $\mathrm{Zn} / \mathrm{ZnO}$ thermochemical cycle. Appli. Energy 2016, 165, 1004-1023. [CrossRef]

65. Meier, A.; Bonaldi, E.; Cella, G.M.; Lipinski, W.; Wuillemin, D. Solar chemical reactor technology for industrial production of lime. Sol. Energy 2006, 80, 1355-1362. [CrossRef]

66. Bellouard, Q.; Abanades, S.; Rodat, S.; Dupassieux, N. Solar thermochemical gasification of wood biomass for syngas production in a high-temperature continuously-fed tubular reactor. Int. J. Hydrog. Energy 2017, 42, 13486-13497. [CrossRef]

67. Steinfeld, A.; Brack, M.; Meier, A.; Weidenkaff, A.; Wuillemin, D. A solar chemical reactor for co-production of zinc and synthesis gas. Energy 1998, 23, 803-814. [CrossRef]

68. Zgraggen, A.; Haueter, P.; Trommer, D.; Romero, M.; Dejesus, J.; Steinfeld, A. Hydrogen production by steam-gasification of petroleum coke using concentrated solar power-II Reactor design, testing, and modeling. Int. J. Hydrog. Energy 2006, 31, 797-811. [CrossRef]

69. Steinfeld, A.; Frei, A.; Kuhn, P.; Wuillemin, D. Solar thermal production of zinc and syngas via combined ZnO-reduction and CH4-reforming processes. Int. J. Hydrog. Energy 1995, 20, 793-804. [CrossRef]

70. Nikulshina, V.; Gebald, C.; Steinfeld, A. $\mathrm{CO}_{2}$ capture from atmospheric air via consecutive CaO-carbonation and $\mathrm{CaCO}_{3}$-calcination cycles in a fluidized-bed solar reactor. Chem. Eng. J. 2009, 146, 244-248. [CrossRef]

71. Gokon, N.; Takahashi, S.; Yamamoto, H.; Kodama, T. Thermochemical two-step water-splitting reactor with internally circulating fluidized bed for thermal reduction of ferrite particles. Int. J. Hydrog. Energy 2008, 33, 2189-2199. [CrossRef] 
72. Gokon, N.; Mataga, T.; Kondo, N.; Kodama, T. Thermochemical two-step water splitting by internally circulating fluidized bed of $\mathrm{NiFe}_{2} \mathrm{O}_{4}$ particles: Successive reaction of thermal-reduction and water-decomposition steps. Int. J. Hydrog. Energy 2011, 36, 4757-4767. [CrossRef]

73. Kodama, T.; Gokon, N.; Yamamoto, R. Thermochemical two-step water splitting by $\mathrm{ZrO}_{2}$-supported $\mathrm{NixFe}_{3}-\mathrm{xO}_{4}$ for solar hydrogen production. Sol. Energy 2008, 82, 73-79. [CrossRef]

74. Taylor, R.W.; Berjoan, R.; Coutures, J.P. Solar gasification of carbonaceous materials. Sol. Energy 1983, 30, 513-525. [CrossRef]

75. Flamant, G.; Hernandez, D.; Bonet, C.; Traverse, J.-P. Experimental aspects of the thermochemical conversion of solar energy; Decarbonation of $\mathrm{CaCO}_{3}$. Sol. Energy 1980, 24, 385-395. [CrossRef]

76. Murray, J. Reaction of steam with cellulose in a fluidized bed using concentrated sunlight. Energy 1994, 19, 1083-1098. [CrossRef]

77. Etori, T.; Gokon, N.; Takeuchi, A.; Miki, T.; Yokota, M.; Kodama, T. Flowability control of bed materials in a fluidized bed reactor for solar thermochemical process. Energy Procedia 2015, 69, 1741-1749. [CrossRef]

78. Furler, P.; Marxer, D.; Scheffe, J.; Reinalda, D.; Geerlings, H.; Falter, C.; Batteiger, V.; Sizmann, A.; Steinfeld, A. Solar kerosene from $\mathrm{H}_{2} \mathrm{O}$ and $\mathrm{CO}_{2}$. AIP Conf. Proc. 2017, 1850, 100006.

79. Gokon, N.; Izawa, T.; Kodama, T. Steam gasification of coal cokes by internally circulating fluidized-bed reactor by concentrated Xe-light radiation for solar syngas production. Energy 2015, 79, 264-272. [CrossRef]

80. Imponenti, L.; Albrecht, K.J.; Wands, J.W.; Sanders, M.D.; Jackson, G.S. Thermochemical energy storage in strontium-doped calcium manganites for concentrating solar power applications. Sol. Energy 2017, 151, 1-13. [CrossRef]

81. Kodama, T.; Gokon, N.; Cho, H.S.; Matsubara, K.; Etori, T.; Takeuchi, A.; Yokota, S.-N.; Ito, S. Particles fluidized bed receiver/reactor with a beam-down solar concentrating optics: 30-kWth performance test using a big sun-simulator. AIP Conf. Proc. 2016, 1734, 120004.

82. Ortiz, C.; Chacartegui, R.; Valverde, J.M.; Alovisio, A.; Becerra, J.A. Power cycles integration in concentrated solar power plants with energy storage based on calcium looping. Energy Convers. Manag. 2017, 149, 815-829. [CrossRef]

83. Säck, J.P.; Breuer, S.; Cotelli, P.; Houaijia, A.; Lange, M.; Wullenkord, M.; Spenke, C.; Roeb, M.; Sattler, C. High temperature hydrogen production: Design of a $750 \mathrm{~kW}$ demonstration plant for a two step thermochemical cycle. Sol. Energy 2016, 135, 232-241. [CrossRef]

84. Tregambi, C.; Montagnaro, F.; Salatino, P.; Solimene, R. Directly irradiated fluidized bed reactors for thermochemical processsing and energy storage: Application to calcium looping. AIP Conf. Proc. 2017, 1850, 090007.

85. Chueh, W.C.; Falter, C.; Abbott, M.; Scipio, D.; Furler, P.; Haile, S.M.; Steinfeld, A. High-flux solar-driven thermochemical dissociation of $\mathrm{CO}_{2}$ and $\mathrm{H}_{2} \mathrm{O}$ using nonstoichiometric ceria. Science 2010, 33, 1797-1801. [CrossRef] [PubMed]

86. Furler, P.; Scheffe, J.R.; Steinfeld, A. Syngas production by simultaneous splitting of $\mathrm{H}_{2} \mathrm{O}$ and $\mathrm{CO}_{2}$ via ceria redox reactions in a high-temperature solar reactor. Energy Envir. Sci. 2012, 5, 6098. [CrossRef]

87. Furler, P.; Scheffe, J.; Gorbar, M.; Moes, L.; Vogt, U.; Steinfeld, A. Solar Thermochemical $\mathrm{CO}_{2}$ Splitting Utilizing a Reticulated Porous Ceria Redox System. Energy Fuels 2012, 26, 121024073702001. [CrossRef]

88. Roeb, M.; Säck, J.-P.; Rietbrock, P.; Prahl, C.; Schreiber, H.; Neises, M.; de Oliveira, L.; Graf, D.; Ebert, M.; Reinalter, W.; et al. Test operation of a $100 \mathrm{~kW}$ pilot plant for solar hydrogen production from water on a solar tower. Sol. Energy 2011, 85, 634-644. [CrossRef]

89. Roeb, M.; Neises, M.; Säck, J.-P.; Rietbrock, P.; Monnerie, N.; Dersch, J.; Schmitz, M.; Sattler, C. Operational strategy of a two-step thermochemical process for solar hydrogen production. Int. J. Hydrog. Energy 2009, 34, 4537-4545. [CrossRef]

90. Buck, R.; Muir, J.F.; Hogan, R.E. Carbon dioxide reforming of methane in a solar volumetric receiver/reactor: The CAESAR project. Sol. Energy Mater. 1991, 24, 449-463. [CrossRef]

91. Gokon, N.; Kodama, T.; Imaizumi, N.; Umeda, J.; Seo, T. Ferrite/zirconia-coated foam device prepared by spin coating for solar demonstration of thermochemical water-splitting. Int. J. Hydrog. Energy 2011, 36, 2014-2028. [CrossRef]

92. Hathaway, B.J.; Chandran, R.B.; Gladen, A.C.; Chase, T.R.; Davidson, J.H. Demonstration of a solar reactor for carbon dioxide splitting via the isothermal ceria redox cycle and practical implications. Energy Fuels 2016, 30, 6654-6661. [CrossRef] 
93. Marxer, D.; Furler, P.; Scheffe, J.; Geerlings, H.; Falter, C.; Batteiger, V.; Sizmann, A.; Steinfeld, A. Demonstration of the entire production chain to renewable kerosene via solar thermochemical splitting of $\mathrm{H}_{2} \mathrm{O}$ and $\mathrm{CO}_{2}$. Energy Fuels 2015, 20, 3241-3250. [CrossRef]

94. Karagiannakis, G.; Pagkoura, C.; Konstandopoulos, A.G.; Tescari, S.; Singh, A.; Roeb, M.; Lange, M.; Marcher, J.; Jové, A.; Prieto, C.; et al. Thermochemical storage for CSP via redox structured reactors/heat exchangers: The RESTRUCTURE project. AIP Conf. Proc. 2017, 1850, 090004.

95. Rosskopf, C.; Afflerbach, S.; Schmidt, M.; Görtz, B.; Kowald, T.; Linder, M.; Trettin, R. Investigations of nano coated calcium hydroxide cycled in a thermochemical heat storage. Energy Convers. Manag. 2015, 97, 94-102. [CrossRef]

96. Rougé, S.; Criado, Y.A.; Huille, A.; Abanades, J.C. Proof of concept of the $\mathrm{CaO} / \mathrm{Ca}(\mathrm{OH})_{2}$ reaction in a continuous heat-exchanger BFB reactor for thermochemical heat storage in CSP plants. AIP Conf. Proc. 2017, 1850, 090005.

97. Chen, C.; Aryafar, H.; Warrier, G.; Lovegrove, K.M.; Lavine, A.S. Ammonia synthesis for producing supercritical steam in the context of solar thermochemical energy storage. AIP Conf. Proc. 2016, 1734, 050010.

98. Lu, J.; Chen, Y.; Ding, J.; Wang, W. High temperature energy storage performances of methane reforming with carbon dioxide in a tubular packed reactor. Appl. Energy 2016, 162, 1473-1482. [CrossRef]

99. Yu, T.; Yuan, Q.; Lu, J.; Ding, J.; Lu, Y. Thermochemical storage performances of methane reforming with carbon dioxide in tubular and semi-cavity reactors heated by a solar dish system. Appl. Energy 2017, 185, 1994-2004. [CrossRef]

100. Villafán-Vidales, H.I.; Abanades, S.; Montiel-González, M.; Romero-Paredes-Rubio, H. Carbo-and methanothermal reduction of tungsten trioxide into metallic tungsten for thermochemical production of solar fuels. Energy Technol. 2017, 5, 692-702. [CrossRef]

101. Gonzalez-Pardo, A.; Denk, T.; Vidal, A. Thermal tests of a multi-tubular reactor for hydrogen production by using mixed ferrites thermochemical cycle. AIP Conf. Proc. 2017, 1850, 100009.

102. Nair, M.M.; Abanades, S. Tailoring hybrid nonstoichiometric ceria redox cycle for combined solar methane reforming and thermochemical conversoin of $\mathrm{H}_{2} \mathrm{O} / \mathrm{CO}_{2}$. Energy Fuels 2016, 30, 6050-6058. [CrossRef]

103. Wokon, M.; Kohzer, A.; Linder, M. Investigations on thermochemical energy storage based on technical grade manganese-iron oxide in a lab-scale packed bed reactor. Sol. Energy 2017, 153, 200-214. [CrossRef]

104. Tescari, S.; Neises, M.; de Oliveira, L.; Roeb, M.; Sattler, C.; Neveu, P. Thermal model for the optimization of a solar rotary kiln to be used as high temperature thermochemical reactor. Sol. Energy 2013, 95, 279-289. [CrossRef]

105. Alonso, E.; Pérez-Rábago, C.; Licurgo, J.; Fuentealba, E.; Estrada, C.A. First experimental studies of solar redox reactions of copper oxides for thermochemical energy storage. Sol. Energy 2015, 115, 297-305. [CrossRef]

106. Arribas, L.; Miroslavov, V.; Bellan, S.; Romero, M.; Gonzalez-Aguilar, J. Development of a solarized rotary kiln for high-temperature chemical processes. In Proceedings of the Solar World Congress, Daegu, Korea, 8-12 November 2015.

107. Michel, B.; Mazet, N.; Neveu, P. Experimental investigation of an open thermochemical process operating with a hydrate salt for thermal storage of solar energy: Local reactive bed evolution. Appl. Energy 2016, 180, 234-244. [CrossRef]

108. Koepf, E.E.; Advani, S.G.; Prasad, A.K.; Steinfeld, A. Experimental investigation of the carbothermal reduction of ZnO using a beam-down, gravity-fed solar reactor. Ind. Eng. Chem. Res. 2015, 54, 8319-8332. [CrossRef]

109. Lapp, J.; Lange, M.; Rieping, R.; de Oliveira, L.; Roeb, M.; Sattler, C. Fabrication and testing of CONTISOL: A new receiver-reactor for day and night solar thermochemistry. Appl. Therm. Eng. 2017, 127, 46-57. [CrossRef]

110. Melchior, T.; Perkins, C.; Lichty, P.; Weimer, A.W.; Steinfeld, A. Solar-driven biochar gasification in a particle-flow reactor. Chem. Eng. Process. Process Intensif. 2009, 48, 1279-1287. [CrossRef]

111. Melchior, T.; Perkins, C.; Weimer, A.W.; Steinfeld, A. A cavity-receiver containing a tubular absorber for high-temperature thermochemical processing using concentrated solar energy. Int. J. Therm. Sci. 2008, 47, 1496-1503. [CrossRef]

112. Piatkowski, N.; Steinfeld, A. Solar-Driven Coal Gasification in a Thermally Irradiated Packed-Bed Reactor. Energy Fuels 2008, 22, 2043-2052. [CrossRef] 
113. Piatkowski, N.; Steinfeld, A. Reaction kinetics of the combined pyrolysis and steam-gasification of carbonaceous waste materials. Fuel 2010, 89, 1133-1140. [CrossRef]

114. Piatkowski, N.; Steinfeld, A. Solar gasification of carbonaceous waste feedstocks in a packed-bed reactor-Dynamic modeling and experimental validation. AIChE J. 2011, 57, 3522-3533. [CrossRef]

115. Schmidt, M.; Gollsch, M.; Giger, F.; Grün, M.; Linder, M. Development of a moving bed pilot plant for thermochemical energy storage with $\mathrm{CaO} / \mathrm{Ca}(\mathrm{OH})_{2}$. AIP Conf. Proc. 2016, 1734, 050041.

116. Alonso, E.; Romero, M. A directly irradiated solar reactor for kinetic analysis of non-volatile metal oxides reductions. Int. J. Energy Res. 2015, 39, 1217-1228. [CrossRef]

117. Schmidt, M.; Gutierrez, A.; Linder, M. Thermochemical energy storage with $\mathrm{CaO} / \mathrm{Ca}(\mathrm{OH})_{2}-$ Experimental investigation of the thermal capability at low vapor pressures in a lab scale reactor. Appl. Energy 2017, 188, 672-681. [CrossRef]

118. Yan, J.; Zhao, C.Y. Experimental study of $\mathrm{CaO} / \mathrm{Ca}(\mathrm{OH})_{2}$ in a fixed-bed reactor for thermochemical heat storage. Appli. Energy 2016, 175, 277-284. [CrossRef]

119. Wieckert, C.; Palumbo, R.; Frommherz, U. A two-cavity reactor for solar chemical processes: Heat transfer model and application to carbothermic reduction of ZnO. Energy 2004, 29, 771-787. [CrossRef]

120. Schaffner, B.; Meier, A.; Wuillemin, D.; Hoffelner, W.; Steinfeld, A. Recycling of Hazardous Solid Waste Material Using High-Temperature Solar Process Heat. 2. Reactor Design and Experimentation. Environ. Technol. 2003, 37, 165-170. [CrossRef]

(C) 2018 by the authors. Licensee MDPI, Basel, Switzerland. This article is an open access article distributed under the terms and conditions of the Creative Commons Attribution (CC BY) license (http://creativecommons.org/licenses/by/4.0/). 